\title{
Maximal Erythrocyte and Hemoglobin Catabolism
}

\author{
Ronald F. Coburn and Peter B. Kane \\ From the Departments of Physiology (Graduate Division) and Medicine, School \\ of Medicine, University of Pennsylvania, Philadelphia, Pennsylvania 19104
}

A в S T R A C T A series of experiments were performed on anesthetized dogs in which varying quantities of normal canine erythrocytes damaged by incubation with $N$-ethylmaleimide were injected into the circulation. Cell sequestration and catabolism of hemoglobin to carbon monoxide remained normal after injections that contained from 0.058 to $0.154 \mathrm{~g}$ of hemoglobin per $\mathrm{kg}$ of body weight.

After administration of larger quantities of these cells, from 0.154 to $0.364 \mathrm{~g}$ of hemoglobin per $\mathrm{kg}$ of body weight, sequestration remained normal but the rate of catabolism of hemoglobin to carbon monoxide reached a maximum. Large quantities of hemoglobin entered the plasma in these experiments at a time when cell sequestration in the reticuloendothelial system appeared to be virtually complete. After injection of even larger quantities of damaged erythrocytes, 0.545 and $0.552 \mathrm{~g}$ of hemoglobin per $\mathrm{kg}$, sequestration became slightly delayed, but was complete.

These data appear to indicate that $(a)$ the maximal rate of hemoglobin catabolism in normal anesthetized dogs averages approximately $0.07 \mathrm{~g} / \mathrm{kg}$ of body weight per hr; $(b)$ hemoglobinemia can result from "overloading" the reticuloendothelial system with damaged sequestered cells and, therefore, may not always indicate "intravascular" hemolysis; and $(c)$ the sequestering function of the reticuloendothelial system appears not to limit the maximal rate of catabolism of hemoglobin. The limiting parameter or parameters were not defined in these studies.

This work was published as an Abstract in the J. Clin. Invest. 1965. 44: 1036.

Dr. Kane's present address is the Department of Anesthesiology, Hospital of the University of Pennsylvania, Philadelphia, Pa. 19104.

Received for publication 31 July 1967 and in revised form 7 February 1968.

\section{INTRODUCTION}

Techniques are now available for investigating the relationships of several parameters of the reticuloendothelial system (RES) that are involved in destruction of circulating erythrocytes and degradation of hemoglobin; however, few measurements have been made of these parameters in controlled experiments. Ideally it would be desirable to study RES function as it is related to the type and extent of damage to erythrocytes, as well as to the quantity of damaged erythrocytes present in the circulation. Previous studies have been concerned with the sites of destruction of damaged erythrocytes as a function of the type of damage to the cell membrane $(1,2)$, and with the effect of varying the quantity of injected nonviable cells on cell sequestration and iron turnover (3). In the present investigation we have studied the effects on several parameters of RES function of varying the quantity of cells damaged in an identical manner. We have made measurements of erythrocyte sequestration and $\mathrm{CO}$ production, an input and output of the RES, after intravenous injections of varying quantities of chemically induced spherocytes into anesthetized dogs. These measurements allowed us to separate the sequestering function of the RES and other processes involved in erythrocyte and hemoglobin catabolism. In a previous study (4) we injected chemically induced spherocytes into the circulation of anesthetized dogs and made measurements of rates of sequestration of these cells and rates of $\mathrm{CO}$ production following cell sequestration; however, the quantities of cells administered in these experiments were not varied over a wide enough range, in order for conclusions to be made regarding the effects of changes of "load" on RES function. In the present study we have extended these data by injecting damaged 
cells containing as much as $0.56 \mathrm{~g}$ of hemoglobin/ $\mathrm{kg}$ of body weight. Data obtained in these experiments have allowed us to determine the quantity of damaged erythrocytes that is sufficient to overload the RES function; and in addition, to study RES functions under conditions where hemoglobin was apparently being catabolized at maximal rates by these organs.

\section{METHODS}

Preparation of the injected erythrocytes. Erythrocytes were prepared from blood drawn from each experimental animal just before the experiment and the cells were treated in an identical manner in each study. The washed cells were incubated for $1 \mathrm{hr}$ at $37^{\circ} \mathrm{C}$ with a solution of $\mathrm{N}$-ethylmaleimide (NEM) in $0.9 \% \mathrm{NaCl}$, giving 64 $\mu$ moles of NEM per $\mathrm{ml}$ of erythrocytes $(5,6)$. Radioactive chromate was also added to the incubate. The cells were collected by centrifugation, washed twice with cold physiological saline, resuspended, and then reinfused intravenously into the donor over a $5 \mathrm{~min}$ period. It has been shown by others (5) that incubation of erythrocytes with NEM in this manner blocks membrane sulfhydryl groups and that after this, cation gradients across the cell membrane are disrupted with resultant electrolyte and water shifts and swelling of the cell. Incubation of erythrocytes with NEM apparently does not influence elution of the chromate label from intact human cells as judged by in vitro studies performed over a $48 \mathrm{hr}$ period in plasma at $37^{\circ} \mathrm{C}(6)$.

In order to evaluate the possibility that the ${ }^{51} \mathrm{Cr}$ label might be lost from dog-NEM-spherocytes before destruction of the cell, we mixed these cells with approximately equal volumes of plasma and agitated them in a flask held at $37^{\circ} \mathrm{C}$ in a water bath. At intervals of $\frac{1}{2}-1 \mathrm{hr}$ the entire cell suspension was centrifuged and the super- natant aspirated so that plasma ${ }^{51} \mathrm{Cr}$ would be removed. Fresh plasma was then added again giving a hematocrit of approximately $50 \%$ and the suspension placed back in the flask. Aliquots were taken over a total time duration of $2 \frac{1}{2}-6 \mathrm{hr}$, counted in a well scintillation counter and the hemoglobin concentration determined. Results from three experiments are shown in Fig. 1. There was no significant decrease in cpm per gram of hemoglobin in any of these experiments, suggesting that the "label" was not lost from intact cells in significant amounts over the $2 \frac{1}{2}-6 \mathrm{hr}$ period. There was significant hemolysis of the NEMspherocytes $(1-2 \% / \mathrm{hr})$ and of course elution of ${ }^{51} \mathrm{Cr}$ from hemolyzed cells.

Measurements of cell sequestration. Rates of sequestration of the injected labeled NEM-spherocytes were estimated from the rate of decrease in radioactivity in peripheral blood assuming that loss from the blood RBC compartment was a result of sequestration in the RES. Venous blood samples were drawn every 5-10 min after injection of the prepared cells, centrifuged at $128 g$ for 20 min, the plasma aspirated and the cells reconstituted to a hematocrit of approximately $50 \%$ with saline. This suspension was counted in a well scintillation counter; the hemoglobin content of the aliquot was determined and radioactivity expressed as cpm per gram of hemoglobin. Total intravascular hemoglobin was determined (7) and a theoretical "initial RBC radioactivity" (in cpm per gram of hemoglobin) by dividing the total injected radioactivity by the total blood hemoglobin. We have expressed the rate of loss of radioactivity from the blood RBC compartment in terms of a half-time, the time after injection when one-half of the injected radioactivity disappeared from the blood RBC fraction. It is noted that a source of error in this method of estimating sequestration of the injected cells is loss of radioactivity from the blood RBC compartment as a result of intravascular hemolysis of the cells before their sequestration in the RES. This will be discussed in a later section of the manuscript.

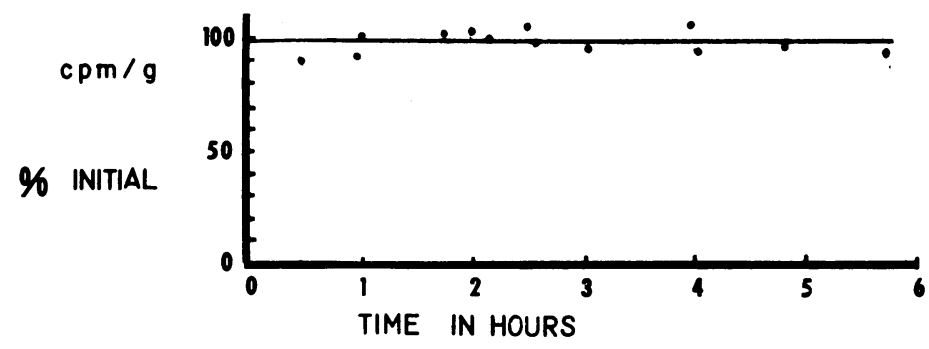

FIGURE 1 Assessment of elution of radiochromate in canine NEMspherocytes. NEM-spherocytes labeled with ${ }^{51} \mathrm{Cr}$ suspended in plasma were agitated briskly in a flask at $37^{\circ} \mathrm{C}$ in an effort to simulate the in vivo environment of these cells in blood. Plasma was removed by centrifugation every 30-60 min and replaced with fresh plasma. Experiments were continued for $2 \frac{1}{2}-6 \mathrm{hr}$. Aliquots of cells were taken periodically and radioactivity expressed as cpm per gram of hemoglobin. Data suggest that elution of the radioactive label did not occur from intact cells. Data from three experiments are shown here, plotted as per cent of initial cpm per gram of hemoglobin. 
At the end of four of the experiments (Nos. 3, 6, 8, and 11) the liver and spleen were removed from the animal, homogenized and diluted, and aliquots counted in a well scintillation counter. These measurements were performed in an effort to identify the sequestration organs in our experiments. The limitations of this approach are discussed in a later section. We also made measurements of plasma radioactivity and plasma volume at the time of removal of these organs so that we could compare total $\mathrm{cpm}$ in liver, spleen, and plasma with that injected. Plasma volume was estimated from $\mathrm{CO}$ dilution and the hematocrit in venous blood (7).

Measurement of the rate of hemoglobin catabolism. The rate of hemoglobin catabolism was estimated from measurements of the rate of endogenous $\mathrm{CO}$ production (8). Excretion of $\mathrm{CO}$ from body stores was prevented by having the experimental animal or subject breathe in a closed system. The rate of $\mathrm{CO}$ production was determined from the rate of increase in body $\mathrm{CO}$ stores, which was calculated from the rate of increase in blood carboxyhemoglobin per cent saturation. In $14-18 \mathrm{~kg}$ dogs the rate of $\mathrm{CO}$ production ( $\nabla \mathrm{CO}$ ) can be measured with a $\mathrm{SD}$ of $\pm 0.02 \mathrm{ml} / \mathrm{hr}$. Sources of error in the measurement of Vco have been extensively discussed elsewhere $(4,8)$. $\mathrm{CO}$ has been shown to be produced in nearly a molar ratio to heme breakdown after injection of NEM-spherocytes into normal man (9) and anesthetized dogs (4). After production of $\mathrm{CO}$ in the RES the processes of diffusion into blood and mixing in the body $\mathrm{CO}$ stores are rapid (10), so that a delay between cell sequestration and measured $\mathrm{CO}$ production appears to be an estimate of time required for transport of hemoglobin intracellularly and the processes involved in hemoglobin catabolism to CO. In the present experiments, as in previous studies, we have determined a base line $\nabla c 0$ and then subtracted this value from total $\mathrm{CO}$ production after cell injection, thereby giving the quantity of $\mathrm{CO}$ produced as a result of catabolism of hemoglobin in the injected cells. This technique assumes that base line $\nabla$ co remains constant. Evidence that this is true was obtained in previous experiments where damaged NEM-spherocytes containing ${ }^{14} \mathrm{C}$-labeled hemoglobin were injected into anesthetized dogs (4) and it was found that ${ }^{14} \mathrm{CO}$ and ${ }^{12} \mathrm{CO}$ yields were not significantly different.

Experimental procedures. 17 mongrel dogs weighing 14-18 $\mathrm{kg}$ were lightly anesthetized with intravenous pentobarbital. A balloon cannula was placed in the trachea and attached to a rebreathing system, similar to that described previously (4), which absorbed $\mathrm{CO}_{2}$ and added $\mathrm{O}_{2}$ as needed. The oxygen tension in the rebreathing system was maintained at approximately $150 \mathrm{~mm} \mathrm{Hg}$. A catheter was placed in the external jugular vein for infusion of saline or dextrose and for blood sampling. Base line $\nabla$ co was determined over the first $2 \mathrm{hr}$ and the prepared cells containing $0.058-0.56 \mathrm{~g}$ of hemoglobin per $\mathrm{kg}$ of body weight were injected slowly over a $5 \mathrm{~min}$ period through the external jugular catheter. Serial blood samples were taken for the measurements of erythrocyte radioactivity, plasma hemoglobin, and blood car- boxyhemoglobin per cent of saturation. The experiments were continued for 4-5 hr post injection.

In two experiments hemoglobin solutions were injested intravenously into the anesthetized animals. In experiment $16,0.146 \mathrm{~g}$ of hemoglobin per $\mathrm{kg}$ of body weight were injected and in experiment $17,0.38 \mathrm{~g} / \mathrm{kg}$ were given. These solutions were prepared by lysing erythro:ytes by freezing and thawing, followed by centrifugation at $3000 \mathrm{~g}$ for $1 \mathrm{hr}$.

Vital statistics and base-line data from each experiment are listed in Table I. It is noted that several of the animals in each group were anemic. The etiology of the anemia in these animals was not investigated hematologically; however, base line Vco and plasma hemoglobin concentrations were normal in most of these animals. The data found in the anemic animals were consistent with those found in "normal" animals.

Analytical measurements. Plasma hemoglobin concentrations were determined with the method of Crosby and Furth (11). Normal values in our dogs averaged $1.5 \pm$ $0.5 \mathrm{mg} / 100 \mathrm{ml}$. Blood carboxyhemoglobin percent of saturation was determined with the method of Coburn, Danielson, Blakemore, and Forster (12).

TABLE I

Vital Statistics and Base Line Data

\begin{tabular}{|c|c|c|c|c|}
\hline $\begin{array}{l}\text { Experi- } \\
\text { ment }\end{array}$ & Weight & $\begin{array}{c}\text { Hemo- } \\
\text { globin } \\
\text { concen- } \\
\text { tration } \\
\text { in blood }\end{array}$ & $\begin{array}{l}\text { Rate } \\
\text { CO } \\
\text { produc- } \\
\text { tion }\end{array}$ & $\begin{array}{l}\text { Plasma } \\
\text { hemo- } \\
\text { globin }\end{array}$ \\
\hline & $\mathrm{kg}$ & $\mathrm{g} / 100 \mathrm{ml}$ & $m l / h r$ & $\mathrm{ml} / 100 \mathrm{ml}$ \\
\hline & \multicolumn{4}{|c|}{ Group A experiments } \\
\hline 1 & 16.8 & 10.6 & 0.16 & 1.0 \\
\hline 2 & 15.6 & 15.4 & 0.21 & $<1$ \\
\hline 3 & 17.2 & 7.04 & 0.17 & 2.1 \\
\hline 4 & 15.4 & 12.1 & 0.17 & 1.5 \\
\hline 5 & 18.1 & 14.8 & 0.20 & 1.1 \\
\hline \multirow[t]{2}{*}{6} & 21.8 & 9.3 & 0.27 & 1.1 \\
\hline & \multicolumn{4}{|c|}{ Group B experiments } \\
\hline 7 & 12.3 & 14.3 & 0.33 & 4.3 \\
\hline 8 & 17.0 & 14.1 & 0.22 & 1.1 \\
\hline 9 & 16.8 & 11.7 & 0.15 & 1.3 \\
\hline 10 & 19.0 & 11.2 & 0.10 & 0.4 \\
\hline 11 & 14.5 & 15.1 & 0.36 & \\
\hline 12 & 18.1 & 14.8 & 0.17 & 3.2 \\
\hline \multirow[t]{2}{*}{13} & 14.1 & 9.3 & 0.11 & 0.3 \\
\hline & \multicolumn{4}{|c|}{ Group $\mathrm{C}$ experiments } \\
\hline 14 & 13.6 & 10.8 & 0.25 & 4.1 \\
\hline \multirow[t]{2}{*}{15} & 16.4 & 11.5 & 0.21 & 0.6 \\
\hline & \multicolumn{4}{|c|}{ Hemoglobin solution experiments } \\
\hline 16 & 13.8 & 9.34 & 0.27 & 0.6 \\
\hline 17 & 12.2 & 12.2 & 0.15 & 0.8 \\
\hline
\end{tabular}




\section{RESULTS}

We have divided the data on the basis of the quantity of hemoglobin in the injected NEMspherocytes. Group A, $0.058-0.139 \mathrm{~g} / \mathrm{kg}$ of body weight; Group B, 0.154-0.364 g/ $\mathrm{kg}$; and Group C, $0.544-0.552 \mathrm{~g} / \mathrm{kg}$. Data from experiments performed in each group are listed in Table II.

Data obtained in the Group A experiments were identical with those obtained previously in normal man (9) and in anesthetized dogs (4). The injected NEM-spherocytes disappeared exponentially from the blood with an average half-time of $9.1 \pm(\mathrm{SE}) 1.2 \mathrm{~min}$. Less than $1 \%$ of the injected radioactivity could be detected in circulating RBC's after $2 \mathrm{hr}$ postinjection; therefore, the injected cells appeared to be almost completely removed from the circulating blood in this time period. CO was produced in excess of base line for an average of $170 \pm(\mathrm{SE}) 14 \mathrm{~min}\left(\mathrm{t}_{\frac{1}{2}} 93=(\mathrm{SE}) 8.2\right.$ min) after injection. Less than $4 \%$ of the hemoglobin in the injected cells appeared in the plasma; this occurred in the 1 st hr after cell injection and

TABLE II

NEM-Spherocyte Injection Experiments

\begin{tabular}{|c|c|c|c|c|c|}
\hline $\begin{array}{l}\text { Experi- } \\
\text { ment }\end{array}$ & $\begin{array}{l}\text { Hemo- } \\
\text { globin } \\
\text { injec- } \\
\text { tion }\end{array}$ & $\begin{array}{l}\text { Sequestration } \\
\text { half-time }\end{array}$ & $\begin{array}{l}\text { Peak } \\
\text { rate } \\
\text { CO pro- } \\
\text { duction }\end{array}$ & $\begin{array}{l}\text { CO produc- } \\
\text { tion half- } \\
\text { time }\end{array}$ & $\begin{array}{l}\text { Highest } \\
\text { plasma } \\
\text { hemo- } \\
\text { globin }\end{array}$ \\
\hline & $\mathrm{g} / \mathrm{kg}$ & $\min$ & $\begin{array}{l}m l / h r \\
\times k g\end{array}$ & $\min$ & $m g / 100 m$ \\
\hline & \multicolumn{5}{|c|}{ Group A experiments } \\
\hline 1 & 0.137 & 7.5 & 0.096 & 100 & 8.0 \\
\hline 2 & 0.113 & 10 & 0.058 & 90 & 8.0 \\
\hline 3 & 0.061 & 7 & 0.032 & 80 & 5.2 \\
\hline 4 & 0.084 & 12 & 0.070 & 80 & 3.4 \\
\hline 5 & 0.058 & & 0.045 & 105 & 5.5 \\
\hline 6 & 0.064 & & 0.047 & 105 & 9.2 \\
\hline \multicolumn{2}{|c|}{ Average and SD } & \multicolumn{2}{|l|}{$9.1 \pm 1.15$} & $93 \pm 5.2$ & \\
\hline & \multicolumn{5}{|c|}{ Group B experiments } \\
\hline 7 & 0.364 & 8 & 0.81 & 100 & 107 \\
\hline 8 & 0.228 & 10 & 0.074 & 110 & 22 \\
\hline 9 & 0.287 & 12 & 0.125 & 120 & 29 \\
\hline 10 & 0.154 & & 0.085 & 105 & 52 \\
\hline 11 & 0.260 & 9 & 0.091 & 90 & 80 \\
\hline 12 & 0.254 & 13 & 0.058 & & 85 \\
\hline 13 & 0.211 & 10 & 0.104 & 90 & 17.5 \\
\hline \multicolumn{2}{|c|}{ Average and sD } & $10.6 \pm 0.8$ & & $107 \pm 6.4$ & \\
\hline & \multicolumn{5}{|c|}{ Group C experiments } \\
\hline 14 & 0.552 & 22 & 0.096 & 120 & 180 \\
\hline 15 & 0.544 & 15 & 0.103 & 120 & 73 \\
\hline
\end{tabular}

presumably resulted from mechanical lysis of cells before their sequestration. The peak rate of $\mathrm{CO}$ production occurred during the $2 \mathrm{nd}$ hr after cell administration; this peak V co measured over an hour period was found to be proportional to the quantity of hemoglobin injected in the NEMspherocytes $(r=0.83)$. CO yields were calculated in the experiments in this group by dividing the total quantity of $\mathrm{CO}$ produced in excess of base line by the quantity of heme injected, both expressed in $\mu$ moles. Average yield was $0.91 \pm$ (SD) 0.075. Data from a typical experiment are depicted in Fig. 2. The relationships of peak Vco to the quantity of NEM-spherocytes injected are shown in Fig. 3.

In the Group B experiments the injected NEMspherocytes were sequestered with an average half-time of $10.6 \pm \mathrm{SE} 0.8 \mathrm{~min}$, a value not significantly different than that found in the Group A experiments $(P>0.05)$. As found in the Group A experiments, virtually all of the injected cells disappeared from the circulating blood within 2 $\mathrm{hr}$. The total time duration in which the Vco was significantly elevated above base line averaged $200 \pm(\mathrm{SE}) 14 \mathrm{~min}$. This was significantly longer than found in the Group A experiments $(P<$ $0.05) \cdot t_{\frac{1}{2}}$ of $\mathrm{CO}$ production averaged $102 \pm \mathrm{SE} 4.2$ min. CO production increased to a peak value during the $2 \mathrm{nd} \mathrm{hr}$, as in the Group A experiments, but remained at this rate for 2-3 hr. Although the plasma contained less than $4 \%$ of the injected hemoglobin $1 \mathrm{hr}$ postinjection when most of the cells had been removed from the blood, hemoglobin entered the plasma during hours 2-5 after injection and reached values ranging from 17.5 to 107 and averaging $56 \mathrm{mg} / 100 \mathrm{ml}$. The circulating erythrocyte radioactivity did not increase during hrs 2-5, suggesting that sequestered cells were not escaping back into blood and that the hemoglobinemia was not a result of hemolysis of escaped cells. The per cent of injected hemoglobin ultimately found in plasma in the experiments in this group varied from 5 to $21 \%$, averaging $13.1 \%$.

The findings in the two experiments listed in Group C were identical with those of Group B, except that sequestration of cells was significantly prolonged, (average $t_{\frac{1}{2}} 18.5 \mathrm{~min}$ ), but sequestration was virtually complete, in that venous blood erythrocyte radioactivity decreased to less than $1 \%$ of the initial value after $2 \mathrm{hr}$. Plasma hemo- 


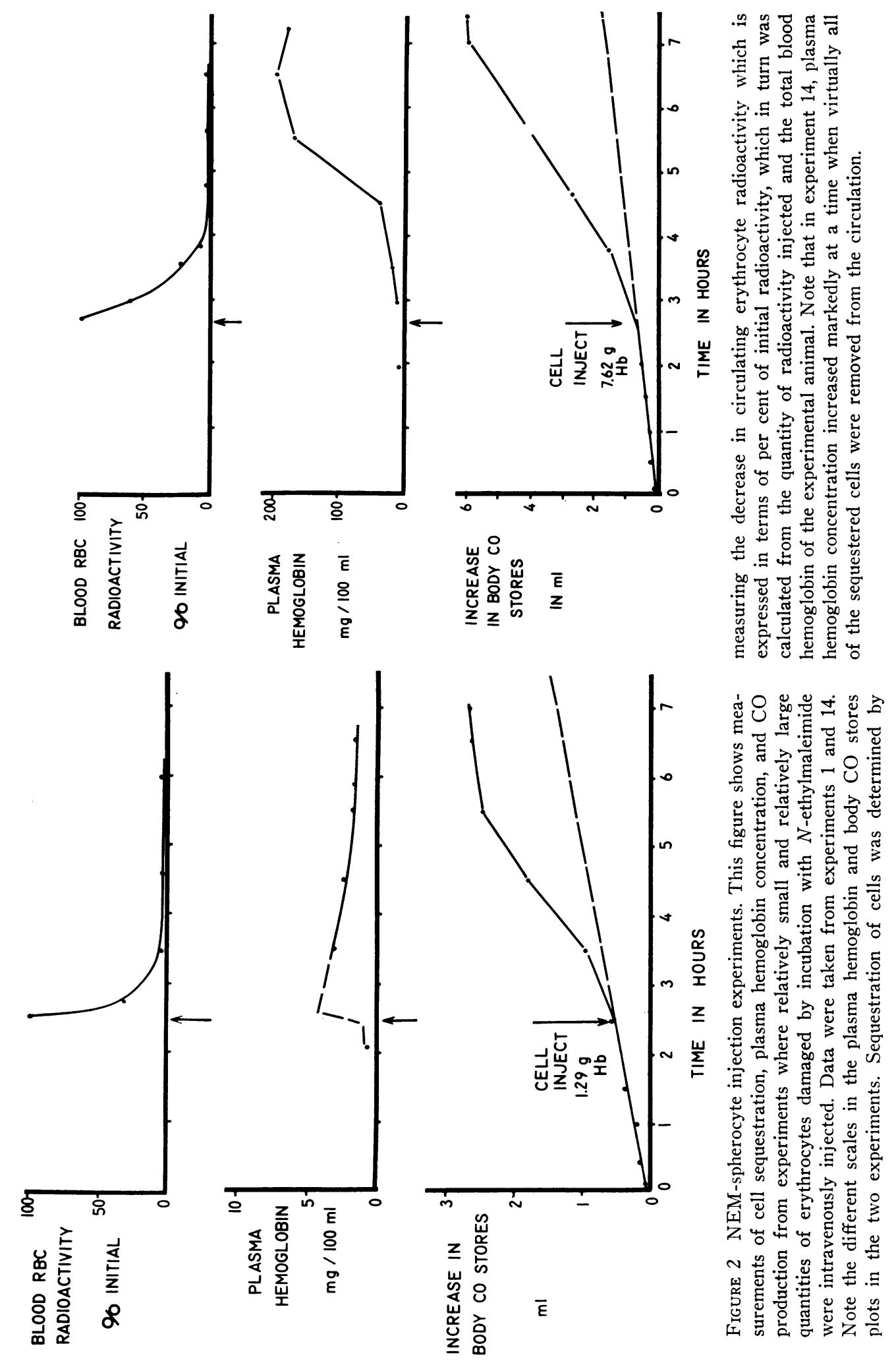






FIGURE 3 The peak rate of CO production in NEM-spherocyte injection experiments. Peak rate of $\mathrm{CO}$ production was defined as the highest rate of $\mathrm{CO}$ production over an hour time interval after cell injection. This figure illustrates that the peak rate of $\mathrm{CO}$ production is proportional to the quantity of cells injected over the range approximately $0.06-0.14 \mathrm{~g}$ of hemoglobin per $\mathrm{kg}$ of body weight, and appears to reach a maximal rate with injections greater than $0.14 \mathrm{gm} / \mathrm{kg}$. The lines through data where the quantities of injected cell were less than or greater than $0.14 \mathrm{gm} / \mathrm{kg}$ are least square regression lines. The regression line through data obtained in experiments where the cells injected contained more than $0.14 \mathrm{~g} / \mathrm{kg}$ has a slope of $0.01 \mathrm{ml} / \mathrm{min}$ per $\mathrm{g}$ which is not significantly different from zero. The open circles denote data obtained in experiments on anemic dogs (blood hemoglobin $<10 \mathrm{~g} / 100 \mathrm{ml}$; $x$ represents the normal rate of $\mathrm{CO}$ production.

globin levels reached 75 and $95 \mathrm{mg} / 100 \mathrm{ml}$ at the end of $3 \mathrm{hr}$ in these experiments, and accounted for 20 and $10.8 \%$ of injected hemoglobin. $\mathrm{CO}$ was produced for an average of $240 \mathrm{~min}\left(\mathrm{t}_{\frac{1}{2}} 120 \mathrm{~min}\right.$ ) after cell injection.

The peak Vco in the Group $\mathrm{B}$ and $\mathrm{C}$ experiments appeared to be independent of the quantity of the hemoglobin injected in the NEM-spherocytes, as illustrated in Fig. 3, and is not propor- tional to the quantity of hemoglobin injected, as found in the Group A experiments. A regression line drawn through the data obtained in Group B and $\mathrm{C}$ experiments (Fig. 3 ) has a slope which is not significantly different from zero $(P>0.50)$. The peak $V_{\text {co }}$ in Group $\mathrm{B}$ and $\mathrm{C}$ experiments averaged $0.091 \pm(\mathrm{SE}) 0.005 \mathrm{ml} / \mathrm{kg}$ per $\mathrm{hr}(1.50$ $\mathrm{ml} / \mathrm{hr}$ ).

In Fig. 4 we have shown sequestration half-

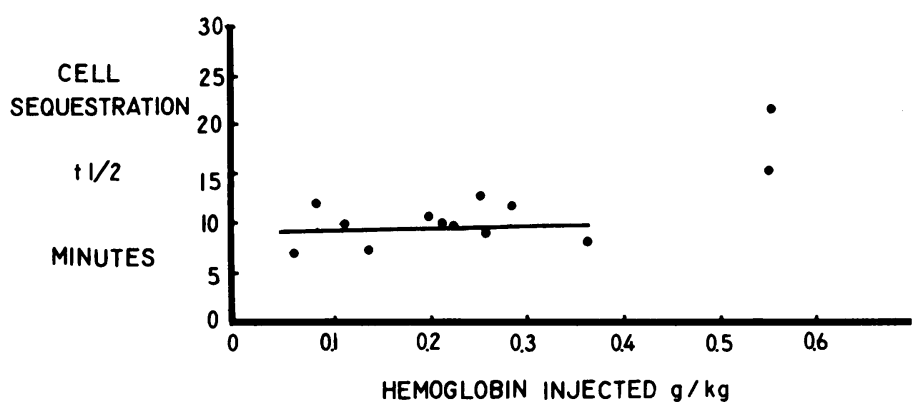

FIGURE 4 Rate of sequestration of the injected NEM-spherocytes. Sequestration rate is expressed in terms of a half-time, which was the time in which one-half of the injected radioactivity disappeared from the blood. There is no change of significance in $t_{\frac{1}{2}}$ in the experiments where cells containing $0.058-0.364 \mathrm{~g}$ of hemoglobin of $\mathrm{kg}$ of body weight were injected. In the two experiments where 0.552 and 0.559 $\mathrm{g} / \mathrm{kg}$ were injected in the NEM-spherocytes, $\mathrm{t}_{2}$ became significantly prolonged. 

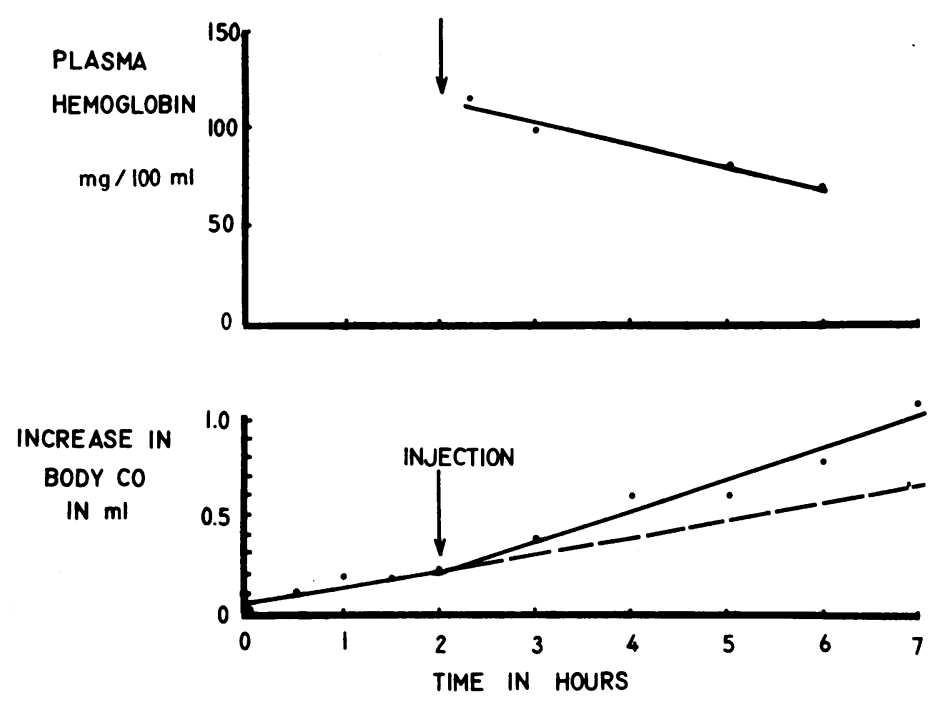

FIgURE 5 Hemoglobin solution injection experiment. This plot illustrates the small increase in the rate of $\mathrm{CO}$ production that occurred after injections of solutions of hemoglobin into the circulation.

times plotted vs. the quantity of hemoglobin injected in the spherocytes. This plot demonstrates that cell sequestration did not become prolonged until loads in excess of about $0.5 \mathrm{~g}$ of hemoglobin per $\mathrm{kg}$ were administered.

It was determined from measurements of liver and spleen radioactivity that approximately all of the injected radiochromate could be recovered from liver and spleen in the Group A experiments. (In experiments 3 and 6, 102.4 and $101.6 \%$ of injected radioactivity was found in these organs.) The partition between liver and spleen was 90.5 and $92.3 \%$, and 11.9 and $9.3 \%$, respectively. In the Group B experiments (Nos. 8 and 11), less than $100 \%$ of the injected radiochromate was recovered in liver and spleen; however, it was shown that the radioactivity of liver and spleen plus plasma was nearly equivalent to that injected in the NEM-spherocytes. In the two experiments, liver and spleen rodioactivities were 91.2 and 95.6, and 6.1 and 9.8, respectively, of injected minus total plasma radioactivity.

Although the plasma hemoglobin became elevated in the Group B and C experiments, urine remained free of hemoglobin, as determined by inspection, in all of these experiments except No. 14 where plasma hemoglobin levels reached 190 $\mathrm{mg} / 100 \mathrm{ml}$.

In the two experiments where hemoglobin solutions were injected, the initial plasma hemoglobin concentrations were 115 and $363 \mathrm{mg} / 100 \mathrm{ml}$. In the former experiment (Fig. 5), plasma hemoglobin decreased at a rate of $12 \mathrm{mg} / 100 \mathrm{ml}$ per hr, corresponding to a loss of $90 \mathrm{mg}$ of hemoglobin per $\mathrm{hr}$ from plasma. $\mathrm{V}$ co increased $0.10 \mathrm{ml} / \mathrm{hr}$ above base line. No hemoglobin was detectable in the urine. In the latter experiment the urinary threshold was exceeded; plasma hemoglobin decreased approximately $30 \mathrm{mg} / 100 \mathrm{ml}$ per $\mathrm{hr}$. In this experiment $V$ co increased $0.15 \mathrm{ml} / \mathrm{hr}$ above base line $\mathrm{V}$ co and remained at this rate as the plasma hemoglobin level decreased from the initial value of $363 \mathrm{mg} / 100 \mathrm{ml}$ to $140 \mathrm{mg} / 100 \mathrm{ml}$ at the end of the experiment.

\section{DISCUSSION}

Previous studies on anesthetized dogs (4) have indicated that NEM-spherocytes containing as much as $0.12 \mathrm{~g}$ of hemoglobin per $\mathrm{kg}$ of body weight can be injected intravenously without changes in the rate or extent of sequestration in the $\mathrm{RES}$, the yield of $\mathrm{CO}$ production, or the kinetics of $\mathrm{CO}$ production after sequestration. Furthermore, plasma hemoglobin did not increase except during the time period when the cells had not been completely removed from the circulating blood. The present experiments have indicated that the RES of the anesthetized dog is able to sequester injected NEM-spherocytes and catabolize their hemoglobin without evidence of overloading the 
system even at loads as great as $0.14 \mathrm{~g}$ of hemoglobin per $\mathrm{kg}$, a quantity that represents over 40 times the normal hourly rate of erythrocyte hemoglobin in our dogs. Sequestration of the injected cells occurred at a rate consistent with complete clearing of the cells during blood flow through the liver and spleen (6). Vco was increased for an average of $170 \mathrm{~min}$ and minimal or no hemoglobin appeared in the plasma after sequestration of the injected cells. In these experiments the peak Vco increased proportionately to the quantity of hemoglobin injected in the NEM-erythrocytes.

In experiments where larger quantities of cells were injected, evidence was obtained that the maximal rate of $\mathrm{CO}$ production by the RES had been reached. Not only did peak Vco remain constant for 2-3 $\mathrm{hr}$ in individual experiments, suggesting that a maximal rate was achieved, but also in these experiments the peak Vco did not increase further as the quantity of injected cells increased. We have termed the peak Vco in these experiments " $\mathrm{VCO}_{\text {max }}$." It is very likely that " $\mathrm{VCO}_{\max }$ " resulted from a maximal rate of hemoglobin catabolism in the Groups B and C experiments. It is remotely possible that the yield of $\mathrm{CO}$ relative to heme catabolism might have decreased in these experiments and that $\mathrm{VCO}_{\max }$ was limited by the oxidation of the heme alpha methine carbon atom, under conditions where a maximal rate of hemoglobin catabolism was not occurring. In most of the experiments, however, all of the injected hemoglobin could be accounted for at the end of the experiments either as that catabolized to $\mathrm{CO}$ (in which a yield of 0.91 is assumed) or as hemoglobin in plasma, supporting the concept that $\mathrm{VCO}_{\max }$ actually resulted from a maximal rate of hemoglobin catabolism.

The experimental finding of $\mathrm{VCO}_{\max }$ was associated with a flux of hemoglobin into plasma. Although the slight increase in plasma hemoglobin that occurred during the $1 \mathrm{st} \mathrm{hr}$ in all of the experiments could possibly be explained by mechanical lysis of cells before their sequestration, the rapid rise in plasma hemoglobin in the Group B and C experiments during $\mathrm{hr} 2-5$ could not be explained on this basis, since virtually all of the injected cells had apparently been sequestered at this time. Furthermore the per cent of total injected hemoglobin that entered the plasma in these experiments was much greater than in the Group A experiments. Since the circulating erythrocyte radioactivity remained at levels less than $1 \%$ of the "initial RBC radioactivity" it seems unlikely that sequestered spherocytes were escaping from the RES into circulating blood, although it is possible that this was occurring and that circulating spherocytes were being lysed very rapidly, These data suggest that hemoglobinemia can occur as a result of failure of the RES to handle large quantities of sequestered damaged cells. Classically, hemoglobinemia has been thought to be secondary to "intravascular hemolysis" and the RES has apparently not been considered to be a factor.

Although the experimental data appear to indicate that overloading the RES with damaged NEM-spherocytes resulted in a maximal rate of hemoglobin catabolism and that this was associated with a flux of hemoglobin into plasma, it has been difficult to determine the limiting RES parameter to erythrocytes and hemoglobin catabolism. We have made measurements of the input of the RES system and an output, but have no data on the intermediate processes involved. The fact that these processes, like the process of sequestration, are not well understood at the present time adds confusion to the issue. Presumably sequestered cells are incorporated into RES phagocytes and hemoglobin is catabolized inside these cells. The evidence that erythrocyte sequestration per se does not occur by phagocytosis either in spleen or liver has been reviewed recently (13-15). This apparently is also true with sequestration of injected carbon and other particles (16). We have used the term "sequestration" to indicate the RES process or processes by which damaged cells are removed from the circulation, and have considered that it is not synonymous with destruction of erythrocytes.

The data obtained in these experiments seem to indicate that sequestration of the injected NEMspherocytes did not limit the rate of hemoglobin catabolism under the conditions of our experiments. Sequestration of these cells was very rapid so that most of the cells were removed from the blood within $45-60 \mathrm{~min}$ after injection. The rate and extent of removal of the cells from circulating blood apparently did not vary even after injection of cells containing over $0.36 \mathrm{~g}$ of hemoglobin per $\mathrm{kg}$ and $\mathrm{VCO}_{\max }$ occurred after much smaller injections of NEM-spherocytes. Our estimates of 
cell sequestration were in error to the extent that hemolysis of the cells occurred in the vascular compartment before sequestration, since this would result in loss of radiochromate from the blood erythrocyte compartment. In all groups of experiments, approximately $5 \%$ of injected cells were apparently hemolyzed intravascularly in the 1 st $\mathrm{hr}$ after injection during the period when the injected cells were being removed from the blood $\mathrm{RBC}$ compartment. However, if this hemolysis was proportional to the quantity of cells remaining in the blood RBC compartment at any time, our calculated $t_{1}$ would not be influenced. Even if all of the hemolysis occurred immediately after cell injection, it is expected that the effect on our calculated $t_{\frac{1}{2}}$ would be the same in all groups of experiments and not influence the finding that sequestration was not delayed in experiments where $\mathrm{VCO}_{\max }$ occurred.

It is, of course, possible that there are "sites" in the RES where damaged cells were sequestered which did not have access to processes involved in degradation of erythrocytes. In this hypothetical situation the number of effective sequestration "sites" could be considered to be limiting. Anatomical studies of spleen have demonstrated that erythrocytes are sequestered in the marginal zone and adjacent areas of the red pulp, and that macrophages may have to travel relatively great distances to reach the sequestered cells (15), so there may be more desirable "sites" in terms of proximity to macrophages in this organ. This may also be true in the liver. It was observed in the present study that the efficiency of sequestration did decrease when cells containing over $0.5 \mathrm{~g}$ of hemoglobin per $\mathrm{kg}$ were injected since the rate of sequestration decreased ( $t_{\frac{1}{2}}$ increased). Even in these experiments, removal of cells from the circulation was complete at the time when most of the hemoglobin appeared in the plasma.

It was not possible in our experiments to be certain that the pattern of sequestration of the NEM-spherocytes was the same in all groups of experiments. Although the percentage of injected minus plasma radiochromate recovered in liver and spleen at the end of the experiment did not change significantly in the Group B experiments (compared with Group A experiments) it is possible this partition may have been influenced by uptake of labeled hemoglobin-haptoglobin and possibly free hemoglobin. It is, however, suggested that the major sites of cell sequestration in these experiments were the liver and spleen, since almost all of the injected radioactivity could be recovered in these organs at the end of the experiments. It is possible that bone marrow, kidney, or other organs were involved to a small extent in sequestration of the injected cells and that the pattern may have varied in these organs as a function of the quantity of cells injected.

The finding that the time duration of $\mathrm{CO}$ production after cell injection increased only slightly following large NEM-spherocyte injections suggests that the life span of sequestered erythrocytes might limit $\mathrm{VCO}_{\max }$. As mentioned above, at the end of $4 \mathrm{hr}$ after injection of cells, virtually all of the injected hemoglobin was either catabolized to $\mathrm{CO}$, or found in plasma, and there could not have been a significant fraction of the cells remaining in the RES. It is suggested that there is a critical time during which sequestered cells can be metabolized without loss of hemoglobin from the RES. $\mathrm{VCO}_{\max }$ could not have been limited only by the life span of sequestered NEM-spherocytes since it occurred during the $2 \mathrm{nd} \mathrm{hr}$ postinjection, when all of the injected cells were sequestered in the RES. It seems very possible that the time duration of hemoglobin catabolism to $\mathrm{CO}$ after cell sequestration and the degree of hemoglobinemia could have been determined by the survival time of sequestered cells in the RES. This may be related to the degree of cell damage at the time of sequestration. NEM-spherocytes hemolyze spontaneously at rates of only about $2-3 \%$ per $\mathrm{hr}$ in acid citrate dextrose (ACD) solution in a constantly rotated tonometer at $37^{\circ} \mathrm{C}$; however, it is possible that the environment of the RES is more deleterious to sequestered erythrocytes than was our tonometer (15).

It is very likely that catabolism of plasma hemoglobin contributed only a relatively small portion of $\mathrm{VCO}_{\max }$. Previous data obtained in experiments where hemoglobin solutions (with the hemoglobin labeled with ${ }^{14} \mathrm{C}$ ) were injected intravenously and ${ }^{14} \mathrm{CO}$ production determined have suggested that the rate of catabolism of hemoglobin-haptoglobin is relatively slow and can augment the rate of $\mathrm{CO}$ production only approximately $0.1 \mathrm{ml} / \mathrm{hr}$. The two additional hemoglobin solution injection experiments included in the present study were 
performed to obtained data where the rate of $\mathrm{CO}$ production was determined directly. (In the previous study $\mathrm{CO}$ production was calculated from rates of production of ${ }^{14} \mathrm{CO}$.) $\mathrm{CO}$ production increased 0.10 and $0.15 \mathrm{ml} / \mathrm{hr}$ compared with control rates in the two experiments, and it is suggested that catabolism of plasma hemoglobin in the Groups B and C NEM-spherocyte injection experiments probably contributed less than $10 \%$ of $\mathrm{VCO}_{\max }$. Direct evidence in support of this concept was obtained in most of the Groups $B$ and $C$ experiments where it was observed that the rate of $\mathrm{CO}$ production decreased to near control rates $4 \mathrm{hr}$ after cell injection at a time when plasma hemoglobin levels were still elevated and plasma hemoglobin presumably being catabolized. A1though the relationships of hemoglobin-haptoglobin complex and erythrocyte hemoglobin catabolism have not been completely clarified, the large difference in the maximal rates in the two cases is evidence against the possibility that intraerythrocyte hemoglobin is catabolized as hemoglobin-haptoglobin complex.

It seems most likely that the RES function that apparently is limiting the rate of catabolism of erythrocyte hemoglobin is related to the quantity of RES cells capable of phagocytosis, or enzyme reactions involved in catabolism of hemoglobin; however, our data do not give evidence in regard to either possibility.

There are several factors in our experiments that may have influenced the measurements of $\mathrm{VCO}_{\max }$, cell sequestration and the behavior of the system during maximal hemoglobin catabolism. The use of pentobarbital as the anesthetic agent may have caused changes in splenic function as a result of pooling of blood in this organ (17). Since our measurements were primarily of liver function (90\% of the injected cells were apparently sequestered in this organ), this should not markedly influence the data. The use of NEM in damaging the injected erythrocytes introduces the possibility that our data cannot be applied to states where erythrocytes are damaged physiologically; however, NEM-spherocytes are considered to be very similar to physiologically aged erythrocytes $(4,5)$ and it seems likely that mechanisms studied in the present investigation are similar to those in operation during destruction of physiologically damaged erythrocytes. The limita- tion of our study to one type of damaged cell had the advantage that this variable was held constant, but also the disadvantage that our measurements may not apply to other types, or varying extent of cell damage. It has been shown by others that the pattern of sequestration is a function of the type and extent of cell damage $(1,2,6)$ and it is expected that $\mathrm{VCO}_{\max }$ would be less if the number of sequestration "sites" available to a damaged cell population is decreased. The fact that NEMspherocytes are sequestered so rapidly (and available information about the patterns of sequestration of these cells (6)) suggests that most or all of the RES tissue available for erythrocyte sequestration is utilized and that, in this sense, $\mathrm{VCO}_{\max }$ determined here is a true maximal rate. The advantages of the use of NEM in this study are that it was relatively easy to keep cell damage constant and that the cells were so rapidly sequestered that it facilitated measurement of the kinetics of $\mathrm{CO}$ production.

It is possible that $\mathrm{VCO}_{\max }$ might vary if the "load" of damaged erythrocytes were presented to the RES at a constant rate, rather than as administered in the present experiment. A single injection of cells had the advantage that the time course of $\mathrm{CO}$ production and influx of hemoglobin into plasma could be determined serially after complete sequestration of injected cells.

There must certainly be error in extrapolating the data obtained in the present studies to normal or pathological man. It is noted that rates of sequestration, the time duration of elevated $\mathrm{CO}$ production, and yield of $\mathrm{CO}$ production, after injections of small quantities of NEM-spherocytes are identical in the anesthetized dog with data obtained in experiments performed in normal unanesthetized human subjects (9), suggesting that results obtained in the present study may be applicable to man.

The average maximal $\mathrm{V}$ co found in the present experiments, $1.5 \mathrm{ml} / \mathrm{hr}$, or $0.092 \mathrm{ml} / \mathrm{hr} \times \mathrm{kg}$ of body weight, is equivalent to a rate of hemoglobin metabolism of approximately $0.07 \mathrm{~g} / \mathrm{hr} \times \mathrm{kg}$. This, in turn, is equivalent to a rate of hemoglobin catabolism in a $70 \mathrm{~kg}$ man of about $5.0 \mathrm{~g} / \mathrm{hr}$ or maximal Vco of $6.7 \mathrm{ml} / \mathrm{hr}$. The largest Vco measured in our laboratory to date is $3.56 \mathrm{ml} / \mathrm{hr}$ in a patient with sickle-cell anemia in a steady state (18). If $\mathrm{VCO}_{\max }$ in man is computed on the basis 
of relative liver weight, an even smaller value is found. Because of this, and since the computed $\mathrm{VCO}_{\max }$ in man is less than two times greater than measured rates of $\mathrm{CO}$ production in patients in a steady state, it seems likely that maximal rates of erythrocyte and hemoglobin catabolism are encountered in patients with acute hemolysis.

It is possible to estimate the number of "sequestration sites" that appear to be available to NEM-spherocytes in the RES of the anesthetized dog. This value is a minimal value since the data indicated that the capacity of the RES to bind the NEM-spherocytes was not exceeded even at the highest "loads" used in our experiments. We have assumed that one sequestered erythrocyte occupies one sequestration "site" and have come up with a value of $1.8 \times 10^{5} / \mathrm{kg}$ of body weight. This corresponds to a value of $1.3 \times 10^{7}$ for a $70 \mathrm{~kg}$ man.

The present experiments appear to represent the first demonstration of the maximal rate of hemoglobin catabolism in any species. Noyes, Bothwell, and Finch (3) studied the effect in normal man of administering varying quantities of ${ }^{59} \mathrm{Fe}$ labeled nonviable cells, prepared by storage at $4^{\circ} \mathrm{C}$ for 24-28 days, and observed that the $t_{1}$ of cell sequestration appeared to increase significantly as cell injections increased from 0.03 to $0.27 \mathrm{~g}$ of hemoglobin per $\mathrm{kg}$ of body weight. There was no evidence given that a maximal rate of erythrocyte destruction was occurring in these experiments, nor could the kinetics of hemoglobin catabolism be accessed from measurements of ${ }^{59} \mathrm{Fe}$ turnover. Plasma hemoglobin levels were markedly elevated in all of these experiments, but due to the relatively slow sequestration of these cells it was not possible to determine if this was secondary to intravascular hemolysis or a mechanism similar to that found in the present study. In the same study, virtually all of the erythrocytes in rabbits were made nonviable by injection of acetylphenylhydrazine. Erythrocytes were removed from the vascular compartment at average rates of approximately $1 \%$ per hr. Extrapolated to man or dog this would be equivalent to rates of destruction of cells of about 35 times the normal rate. It seems possible that a maximal rate of erythrocyte catabolism, and perhaps hemoglobin catabolism, was occurring in these latter experiments. The calculated rate is similar to that found in the present study.
Although our experiments imply that hemoglobinemia may result from RES "overload," there seems little doubt that intravascular hemolysis occurs. Jandl and Kaplan have clearly related hemoglobinemia to the degree or rapidity of membrane damage (2). It seems likely that the pathogenesis of hemogloblinemia in hemolytic anemia may include alterations in a multitude of variables. The variables that may be involved include $(a)$ rate and extent of erythrocyte membrane damage, $(b)$ the quantity of cells involved, $(c)$ hazards in the circulation for damaged erythrocytes, $(d)$ rate of blood flow through RES, $(e)$ RES organs involved in sequestration, $(f)$ number of sequestration "sites," $(g)$ affinity of the bond between sequestered cells and RES, $(h)$ number, accessibility and activity of phagocytic cells, and ( $i)$ quantity and accessibility of enzymes needed for degration of hemoglobin.

It is of interest that $\mathrm{VCO}_{\max }$ were not significantly different in the group of animals that were anemic, compared with nonanemic animals. A1though the anemia in these animals was not explained, apparently anemia per se does not alter the limiting parameter or parameters to maximal hemoglobin destruction.

\section{ACKNOWLEDGMENTS}

We gratefully acknowledge the technical assistance of Robert Ersek and the encouragement and assistance of Doctors Robert E. Forster and William J. Williams.

This work was supported in part by Grant RO1 HE 10331 from the National Heart Institute, Bethesda, Md. Dr. Ronald F. Coburn is a recipient of Career Development Award 5-K3-HE-11,564 from the National Heart Institute, Bethesda, Md.

\section{REFERENCES}

1. Jandl, J. H., A. R. Jones, and W. B. Castle. 1957. The destruction of red cells by antibodies in man. Observations on the sequestration and lysis of red cells altered by immune mechanisms. J. Clin. Invest. 36: 1428.

2. Jandl, J. H., and M. E. Kaplan. 1960. The destruction of red cells by antibodies in man. III. Quantitative factors influencing patterns of hemolysis in vivo. J. Clin. Invest. 39: 1145.

3. Noyes, W. D., T. H. Bothwell, and C. Finch. 1960. The role of the reticulo-endothelial cell in iron metabolism. Brit. J. Haemat. 6: 43.

4. Coburn, R. F., W. J. Williams, P. White, and S. B. Kahn. 1967. The production of carbon monoxide from hemoglobin in vivo. J. Clin. Invest. 46: 346. 
5. Jacob, H. S., and J. H. Jandl. 1962. Effects of sulthydryl inhibition on red blood cells. I. Mechanism of hemolysis. J. Clin. Invest. 41: 779.

6. Jacob, H. S., and J. H. Jand1. 1962. Effect of sulfhydryl inhibition on red blood cells. II. Studies in vivo. J. Clin. Invest. 41: 1514.

7. Sjöstrand, T. 1948. A method for the determination of the total volume hemoglobin content of the body. Acta Physiol. Scand. 16: 211.

8. Coburn, R. F., W. S. Blakemore, and R. E. Forster. 1963. Endogenous carbon monoxide production in man. J. Clin. Invest. 42: 1172.

9. Coburn, R. F., W. J. Williams, and R. E. Forster. 1964. Effect of erythrocyte destruction on carbon monoxide production in man. J. Clin. Invest. 43: 1098.

10. Coburn, R. F., and K. Luomanmäki. 1966 Effect of $\mathrm{CO}$ production, distribution and metabolism on blood [COHB]. Physiologist. 9: 156.

11. Crosby, W. H., and F. W. Furth. 1956. A modification of the benzidine method for measurement of hemoglobin in plasma and urine. Blood. 11: 380 .

12. Coburn, R. F., G. K. Danielson, W. S. Blakemore, and R. E. Forster. 1964. Carbon monoxide in blood: analytical method and sources of error. J. Appl. Physiol. 19: 510.

13. Jandl, J. H., N. M. Files, S. B. Barnett, and R. A. MacDonald. 1965. Proliferative response of the spleen and liver to hemolysis. J. Exptl. Med. 122: 299.

14. Jandl, J. H. 1964. Mechanism of immune hemolysis in vivo. In Injury, Inflammation and Immunity. L. Thomas, J. W. Uhr, and L. Grant, editors. Williams \& Wilkins Co., Baltimore.

15. Jandl, J. H., and R. H. Aster. 1967. Increased splenic pooling and the pathogenesis of hypersplenism. Am.J. Med. Sciences. 253: 383.

16. Snook, T. 1964. Studies on the perifollicular region of the rat's spleen. Anat. Records. 148: 149.

17. Reeve, E. B., M. I. Gregerson, T. H. Allen, and H. Sear. 1953. Distribution of cells and plasma in the normal and splenectomized dog and its influence on blood volume estimated with $\mathrm{P}^{32}$ and $\mathrm{T}-1824 . \mathrm{Am}$. J. Physiol. 175: 195.

18. Coburn, R. F., W. J. Williams, and S. B. Kahn. 1966. Endogenous carbon dioxide production in patients with hemolytic anemia. J. Clin. Invest. 45: 460. 